\title{
SISTEM KOREKSI POSTUR DUDUK DENGAN BETASPC BERBASIS ARDUINO DUEMILANOVE
}

\author{
Mukti Budiarto ${ }^{1}$ \\ Andri Ahmad Gozali ${ }^{2}$ \\ Hidayaturrohman ${ }^{3}$ \\ Dosen AMIK Raharja Informatika Jurusan Teknik Informatika ${ }^{1}$, Alumni STMIK Raharja Jurusan \\ Sistem komputer ${ }^{2}$, Alumni STMIK Raharja Jurusan Sistem komputer ${ }^{3}$ \\ Jl. Jendral Sudirman No. 40, Modernland, Tangerang \\ Email:mukti@raharja.info,andrizali@raharja.info,hi_dayaturrohman@yahoo.com
}

Diterima: 5 Juli 2016 / Disetujui 19 Juli 2016

\begin{abstract}
BetaSPC is a technology that uses a microcontroller (Arduino Duemillanove) as processors and sensors (infrared) which is based on the amount of light reflected on a clothes stretched (when the bent body position). With the technology used in BetaSPC allows one to determine the proper posture when sitting at a computer or laptop and improve posture during sitting. When someone is in front of the laptop or computer by sitting in an upright posture, the posture shoulder (shoulder) on the back will change clothes behind, just below the shoulder blade position becomes meragang. If someone sitting at a computer or laptop to a sitting position in a bent posture then clothes (clothes) behind, just below the shoulder blade will be stretched (tight). Then, stretch clothes that will activate the buzzer (sound and vibrate) to provide feedback to the user about the current posture stretch shirt (hunchback) so as to commemorate and improve the position of his body correctly (perpendicular) when using a computer or laptop.
\end{abstract}

Keywords: BetaSPC, Arduino Duemillanove, Infrared, Buzzer

\section{ABSTRAK}

BetaSPC adalah sebuah teknologi yang menggunakan mikrokontroller (Arduino Duemillanove) sebagai prosesor dan sensor (infrared) yang didasarkan pada jumlah cahaya yang dipantulkan pada sebuah pakaian yang meregang (pada saat posisi tubuh membungkuk). Dengan teknologi yang digunakan dalam BetaSPC memungkinkan seseorang untuk mengetahui posisi tubuh yang benar ketika duduk di depan komputer atau laptop dan meningkatkan postur tubuh selama duduk. Ketika seseorang berada di depan laptop atau komputer dengan posisi duduk dalam postur tubuh yang tegak lurus, maka postur pundak (bahu) di belakang akan merubah baju di belakang, posisinya tepat dibawah tulang belikat menjadi tidak meragang. Jika seseorang duduk di depan komputer atau laptop dengan posisi duduk dalam postur tubuh yang membungkuk maka baju (pakaian) dibelakang, tepat di bawah tulang belikat akan meregang (ketat). Kemudian, baju yang meregang akan mengaktifkan buzzer (suara dan vibrates) untuk memberikan feedback ke user tentang postur tubuh saat baju meregang (bungkuk) sehingga dapat memperingati dan memperbaiki posisi tubuhnya dengan benar (tegak lurus) pada saat menggunakan komputer atau laptop.

Kata kunci: BetaSPC, Arduino Duemillanove, Infrared, Buzzer

\section{PENDAHULUAN}

Komputer, Notebook (Laptop) dan sejenisnya, tidak bisa dipungkiri telah menjadi bagian dari kebutuhan hidup masyarakat di seluruh dunia. Seseorang dapat memendangi komputer selama 8 jam perhari untuk mengerjakan pekerjaan kantor, tugas kuliah, browsing, chatting, blogging, mengunjungi forum, check email, bermain, belajar dan sebagainya. Ini berarti 8 jam duduk di komputer, yang mungkin tidak menjaga posisi tubuh saat duduk secara ideal. Posisi duduk saat menggunakan komputer memang terkait dengan efektifitas kerja. Posisi duduk yang 
baik membuat tidak lelah dan nyaman ketika bekerja.

Perguruan Tinggi Raharja merupakan salah satu institusi pendidikan yang bergerak di bidang teknologi informasi. Untuk itu, Perguruan Tinggi Raharja terus menerus melakukan peningkatan dan pengembangan, baik berupa sistem pembelajaran kampus maupun sistem pelayanan yang ditetapkan di Perguruan Tinggi Raharja. Sehingga setiap pembelajaran di Perguruan Tinggi Raharja pasti menggunakan komputer sesuai dengan jurusan pada Perguruan tinggi Raharja adalah ilmu komputer dan informatika.

BetaSPC (Sitting Posture Correction) Beta version merupakan ruang lingkup sistem komputer dengan mengeksplorasi teknologi pada koreksi postur duduk ketika di depan komputer yang masih perlu dikembangkan (versi Beta). Sistem ini dapat dilakukan di setiap ruangan pada Perguruan Tinggi Raharja yang memfasilitasi komputer bagi mahasiswa dan staff dukungan teknis, dosen, dan sebagainya dalam melakukan pekerjaan yang memakan waktu lama. Sehingga dijadikan dasar untuk dilakukan penelitian terkait BetaSPC. Pengujian teknologi ini, dapat dilakukan pada Perpustakaan Raharja misal oleh petugas, di Lab iLearning, Ruang Praktikum, RIC (Raharja Internet Cafe), REC (Raharja Enrichment Centre), RCEP (Raharja Certified English Proficiency), dan lain-lain, tujuannya untuk mendapati hasil pengujian. Sehingga apakah cukup memberikan manfaat dan jika perlu dikembangkan apakah yang perlu dilakukan.

Selain itu yang menjadikan dasar dari penelitian ini bahwa ada suatu penelitian mengungkapkan bekerja dengan dapat memungkinkan terjadinya berbagai gangguan kesehatan. Namun yang paling utama adalah tulang terutama bahu, punggung, pinggang bagian bawah, dikutip dari (http://www.tanyadok.com).

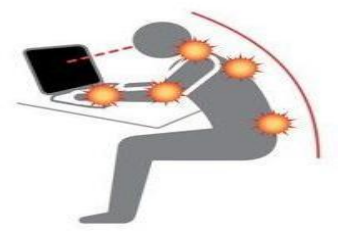

Gambar 1. Gangguan postur duduk di komputer

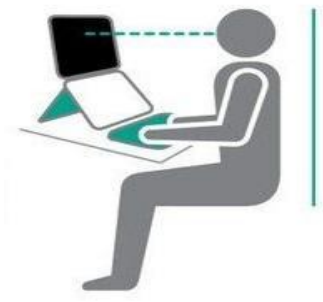

Gambar 2. Postur duduk yang benar di komputer

Para ahli memperkirakan bahwa sebanyak $80 \%$ dari populasi yang ada di seluruh dunia akan mengalami masalah kesehatan pada beberapa waktu di kehidupan. Sebagian orang yang menyadari hal ini, tetapi tidak mengambil tindakan apapun saat dia bekerja. (Amerika Chiropractic Association, 2015).

\section{PERMASALAHAN}

Ergonomi adalah ilmu yang mempelajari perilaku manusia dalam kaitannya dengan pekerjaan mereka. Sasaran penelitian ergonomi adalah manusia pada saat bekerja dalam lingkungan. Penyakit ergonomik merupakan salah satu penyakit akibat kerja, dan sasaran peneliti merupakan kerja di komputer.

Di antara masalah kesehatan yang dialami ketika berada di depan komputer atau laptop seperti penglihatan, jari-tangan, dll. Namun ada masalah yang utama yang justru sering diabaikan orang-orang, posisi duduk yang membungkuk ketika di depan komputer, jika ini terus dilakukan berulang (repetitif) dalam jangka waktu lama akan mengakibatkan kerusakan pada tulang dan berakibat terjadinya kifosis.

Permasalahan lainnya adalah kita tidak ada waktu untuk beristirahat ketika duduk karena dituntut untuk bekerja di depan komputer seperti yang ada di REC. Hal ini mengakibatkan para staff atau dosen yang bekerja merasa butuh suatu teknologi yang dapat memberikan indikator jika postur tubuh berubah sehingga dapat memberikan informasi pada user bahwa postur tubuh yang terjadi sedang membungkuk. 


\section{LANDASAN TEORI DAN LITERATURE REVIEW}

\section{LANDASAN TEORI}

- $\quad$ Arduino Duemilanove

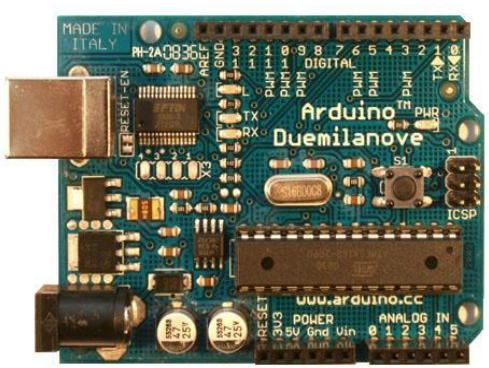

Gambar 3. Arduino Duemilanove Board (http://arduino.cc)

Arduino Duemilanove adalah mikrokontroler berdasarkan ATmegal68 (datasheet) atau ATmega328 (datasheet). memiliki 14 digital pin $1 / O$ (dimana 6 dapat digunakan sebagai output PWM), 6 input analog, osilator kristal $16 \mathrm{MHz}$, koneksi USB, jack listrik, header ICSP, dan tombol reset. berisi semua yang diperlukan untuk mendukung mikrokontroler; hanya terhubung ke komputer dengan kabel USB atau dengan adaptor AC-DC atau baterai untuk dapat memulai.

Tabel 1. Spesifikasi Board Arduino Duemilanove

\begin{tabular}{|l|l|}
\hline \multicolumn{1}{|c|}{ Nama } & Deskripsi \\
\hline Mikrokontroler & $\begin{array}{l}\text { Atmega16 } \\
8 / 328\end{array}$ \\
\hline Operating Voltage & $5 \mathrm{~V}$ \\
\hline $\begin{array}{l}\text { Input Voltage } \\
\text { (Recommended) }\end{array}$ & $7-12 \mathrm{~V}$ \\
\hline $\begin{array}{l}\text { Input Voltage } \\
\text { (limits) }\end{array}$ & $6-20 \mathrm{~V}$ \\
\hline Digital I/O Pins & $\begin{array}{l}14 \\
\text { diberikan } \\
\text { output } \\
\text { PWM) }\end{array}$ \\
\hline Analog Input Pins & 6 \\
\hline
\end{tabular}

\begin{tabular}{|l|l|}
\hline $\begin{array}{l}\text { DC Current per I/O } \\
\text { Pin }\end{array}$ & $40 \mathrm{~mA}$ \\
\hline $\begin{array}{l}\text { DC Current for } \\
\text { 3.3V Pin }\end{array}$ & $50 \mathrm{~mA}$ \\
\hline Flash memory & $16 \mathrm{~KB}$ \\
\hline SRAM & $1 \mathrm{~KB}$ \\
\hline EEPROM & $512 \mathrm{byte}$ \\
\hline Clock Speed & $16 \mathrm{MHz}$ \\
\hline
\end{tabular}

Arduino Duemilanove dapat diaktifkan melalui koneksi USB atau dengan catu daya eksternal. Catu daya eksternal (non-USB) bisa digunakan baik dari adaptor AC-DC atau baterai. Adaptor dapat dihubungkan dengan mencolokkan steker $2.1 \mathrm{~mm}$ pusat-positif ke colokan listrik. Kedua adalah melalui baterai dapat dimasukkan dalam gnd dan Vin pin header konektor daya.

Papan dapat beroperasi pada pasokan eksternal 6 sampai 20 volt. Jika disertakan dengan kurang dari $7 \mathrm{~V}$, bagaimanapun, $5 \mathrm{~V}$ pin dapat dipasok kurang dari lima volt dan papan mungkin tidak stabil. Jika menggunakan lebih dari $12 \mathrm{~V}$, regulator tegangan bisa panas dan merusak papan pada Arduino duemilanove. Kisaran yang disarankan yaitu 7 sampai 12 volt, tidak lebih dari itu. Berikut ini merupakan pin pada power di Arduino Duemilanove beserta penjelasannya di tabel 2 :

Tabel 2 Keterangan Pin Power Arduino Duemilanove

\begin{tabular}{|l|l|}
\hline Vin & $\begin{array}{l}\text { Input tegangan ke Arduino } \\
\text { ketika menggunakan daya } \\
\text { eksternal (+). }\end{array}$ \\
\hline $5 \mathrm{~V}$ & $\begin{array}{l}\text { Power supply yang diatur } \\
\text { digunakan untuk daya arduino } \\
\text { dan komponen lain. }\end{array}$ \\
\hline 3.3 & $\begin{array}{l}\text { Sebuah pasokan 3,3 volt yang } \\
\text { dihasilkan oleh chip FTDI on- } \\
\text { board. }\end{array}$ \\
\hline Gnd & Pin Ground (-) \\
\hline
\end{tabular}




\section{A. INPUT DAN OUTPUT}

Masing-masing dari 14 pin digital pada Duemilanove dapat digunakan sebagai I/O, menggunakan fungsi pinMode (), digitalWrite (), dan digitalRead (). Beroperasi di 5V. Setiap pin dapat memberi dan menerima maksimum $40 \mathrm{~mA}$. Memiliki resistor pull-up internal yang terputus secara default dari 20-50 kOhms. Selain itu, beberapa pin punya yang fungsi khusus.

Tabel 3 Keterangan I/O Pin Arduino Duemilanove

\begin{tabular}{|l|l|}
\hline $\begin{array}{l}\text { Serial: 0 (RX) } \\
\text { dan 1 (TX) }\end{array}$ & $\begin{array}{l}\text { Digunakan untuk } \\
\text { menerima (RX) dan } \\
\text { mengirimkan (TX) TTL } \\
\text { data serial. Pin ini } \\
\text { terhubung ke pin yang } \\
\text { sesuai dari FTDI USB- } \\
\text { to-TTL Serial Chip. }\end{array}$ \\
\hline $\begin{array}{l}\text { Interupsi } \\
\text { eksternal: 2 dan } \\
3\end{array}$ & $\begin{array}{l}\text { Pin ini dapat di } \\
\text { konfigurasi memicu } \\
\text { interupsi pada nilai } \\
\text { rendah atau tinggi atau } \\
\text { jatuh-tepi, atau } \\
\text { perubahan nilai. }\end{array}$ \\
\hline $\begin{array}{l}\text { PWM: } \\
3,5,6,9,10 \\
11\end{array}$ & $\begin{array}{l}\text { Memberikan 8-bit pada } \\
\text { PWM output dengan } \\
\text { fungsi: analogWrite () }\end{array}$ \\
\hline $\begin{array}{l}\text { SPI 10 (SS), 11 } \\
\text { (MOSI), } \\
\text { (MISO), } \\
\text { (SCK) }\end{array}$ & $\begin{array}{l}\text { pin ini mendukung } \\
\text { komunikasi } \\
\text { menggunakan SPI } \\
\text { perpustakaan SPI. }\end{array}$ \\
\hline LED: 13 & $\begin{array}{l}\text { Built-in LED terhubung } \\
\text { ke pin digital 13. Ketika } \\
\text { pin ini berupa nilai } \\
\text { High LED on dan } \\
\text { ketika pin Low LED off. }\end{array}$ \\
\hline
\end{tabular}

\begin{tabular}{|l|l|}
\hline I2C & $\begin{array}{l}\text { Pin input analog A4 (SDA) dan } \\
\text { A5 (SCL) yang mendukung I2C } \\
\text { (TWI) komunikasi dengan } \\
\text { library. }\end{array}$ \\
\hline AREF: & $\begin{array}{l}\text { Referensi tegangan untuk input } \\
\text { analog }\end{array}$ \\
\hline Reset: & $\begin{array}{l}\text { membawa garis LOW untuk } \\
\text { reset mikrokontroler. }\end{array}$ \\
\hline
\end{tabular}

\section{B. KOMUNIKASI}

Arduino Duemilanove ini menyediakan UART TTL (5V) komunikasi serial, yang tersedia pada pin digital 0 (RX) dan 1 (TX). Sebuah FTDI FT232RL pada saluran komunikasi serial ini melalui USB dan papan driver FTDI (disertakan dengan Windows versi software Arduino) menyediakan port com virtual untuk perangkat lunak pada komputer. Software Arduino termasuk Serial monitor yang memungkinkan data tekstual sederhana yang akan dikirim ke dan dari papan Arduino. RX dan TX LED di papan akan berkedip ketika data sedang dikirim melalui chip FTDI dan USB koneksi ke komputer (tetapi tidak untuk komunikasi serial pada pin 0 dan 1). mendukung I2C (TWI) dan mendukung komunikasi SPI.

\section{PROGRAMMING}

Arduino Duemilanove dapat diprogram dengan software Arduino IDE (Integrated Development Environment) bersifat open-source. Pilih "Arduino Duemilanove Diecimila atau w / ATmega168" atau "Arduino Duemilanove w / ATmega328" dari menu Tools > Board (sesuai dengan mikrokontroler pada komputer itu). Pada Arduino Duemilanove datang dengan suatu bootloader yang memungkinkan Anda untuk meng-upload kode baru untuk itu tanpa menggunakan programmer hardware. Komunikasi menggunakan protokol asli STK500, juga dapat cut bootloader dan program mikrokontroler dari ICSP (In-Circuit Serial Programming).

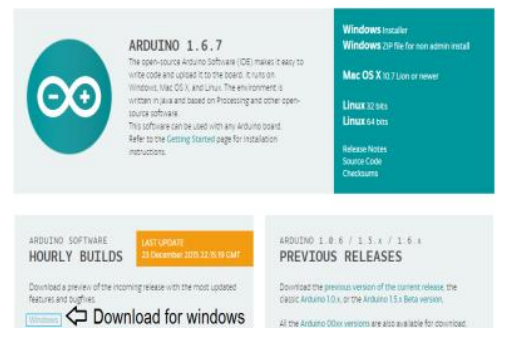

Gambar 4. Software Arduino IDE

\section{Reciever)}

- IR Sensor (Transmitting dan

Secara Fisik Cahaya IR mirip dengan cahaya LED (Light Emitting Diode), Bedanya IR memiliki panjang gelombang sedikit lebih 
panjang. Kedua adalah IR tidak terdeteksi oleh mata manusia, digunakan untuk komunikasi nirkabel. Sebagai contoh, ketika sedang menekan tombol remote TV, IR LED berulang-kali nyala dan mati $38.000 \mathrm{X}$, ketiga untuk mengirimkan informasi (seperti volume atau saluran kontrol) ke IR Sensor photodiode di TV (http://learn.sparkfun.com).

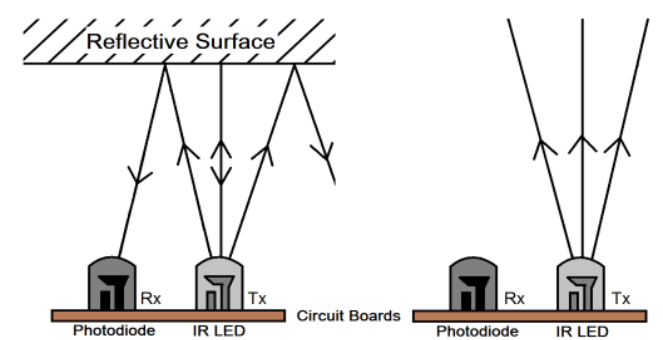

Gambar 5. Ilustrasi Kerja Transmitting IR LED dan Receiving IR Photo Sensor

Dasar Komunikasi IR sensor secara sederhana adalah ketika menggunakan remote TV suatu IR LED digunakan untuk mengirimkan informasi ke TV. IR Photo sensor menerima sinyal dari jarak jauh dengan menggunakan IR sinyal modulasi. Kerja sinyal modulasi menugaskan pola suatu data, sehingga penerima tahu dan memilih sinyal dari semua IR yang berada disekiar.

Meskipun kita sebagai manusia tidak mampu melihat sinar infra merah, bukan berarti kita tidak bisa membuatnya menjadi tampak. Sebuah video kamera atau digital foto dapat "melihat"nya, sebagaimana yang bisa dilihat pada gambar 4 dibawah ini. WEBCam anda mampu menerima cahaya ini dengan baik. Silahkan arahkan remote pada sebuah WEBCam, lalu tekan sembarang tombol. Anda akan melihat LED pada remote berkedip. Kedipan ini karena adanya modulasi yang dikirimkan melalui infrared LED. Penggunaan modulasi dimaksudkan untuk mencegah kesalahan penerima (receiver) dalam menerjemahkan data dari pengirim (transmitter).

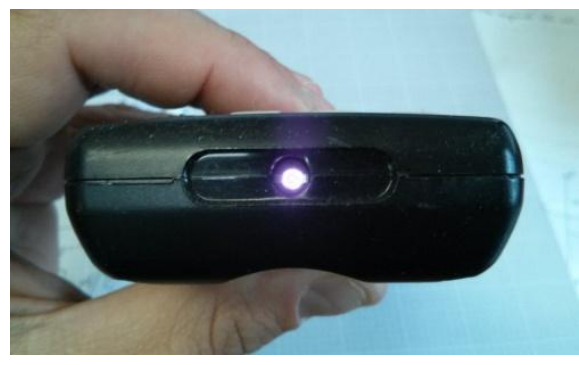

Gambar 6. Cahaya IR Remote TV
Skema modulasi umum untuk komunikasi IR yaitu $38 \mathrm{kHz}$. Data modulasi IR $38 \mathrm{kHz}$ paling umum, tetapi frekuensi lain bisa digunakan. Ketika menekan tombol remote $\mathrm{TV}$, transmisi IR LED akan berkedip sangat cepat sepersekian detik dan transmisi data akan dikodekan ke alat.

Modulasi adalah jawaban mencegah sinyal menjadi kebal terhadap noise (gangguan). Dengan modulasi membuat sumber IRLED berkedip pada frekuensi tertentu. Penerima IR akan diatur pada frekuensi itu sehingga semua frekuensi lain akan diabaikan. Pada gambar 5, di bawah terlihat sinyal sudah dimodulasi diperkuat oleh transistor yang digunakan untuk menyalakan LED yaitu gambar sebelah kiri. Dan pada gambar kanan terlihat bahwa sinyal ini akan diterima oleh penerima IR yang kemudian akan diterjemahkan dengan kondisi tertentu 30 hingga $60 \mathrm{kHz}$.

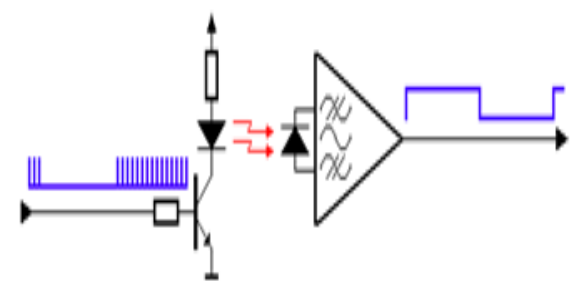

Gambar 7. IR Transmitter dan Receiver Bekerja

\section{- $\quad$ Buzzer}

Buzzer adalah salah satu komponen elektronika yang dapat mengeluarkan bunyi/suara. Suara yang dihasilkan tergolong sederhana yakni (monofonik), beda dengan speaker yang dapat mengeluarkan suara yang lebih variatif (polifonik). Buzzer terbuat dari rangkaian piezo electric, yang bergetar dan menimbulkan suara ketika diberi tegangan DC yang dimasukan ke piezo electric, dan mendapati nada bunyi yang berbeda. Demikian kurang lebih prinsip kerja di buzzer.

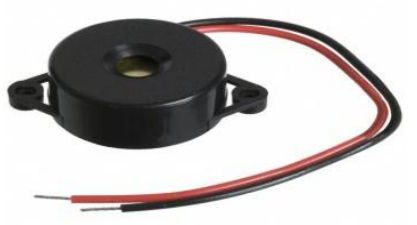

Gambar 8. Piezo Buzzer 
Sebuah buzzer dapat langsung dikoneksikan ke arduino tergantung impendansinya. Jika impendansi kurang dari $10 \mathrm{ohm}$, maka dapat langsung menghubungkannya dengan/ke arduino. Untuk impedansi yang lebih besar membutuhkan driver untuk mengangkat arus yang masuk ke buzzer. Cara termudah dan sederhana membuat driver untuk buzzer adalah menggunakan rangkaian transistor. berikut adalah rangkaian transistor berbentuk skematik dilihat di gambar 9:

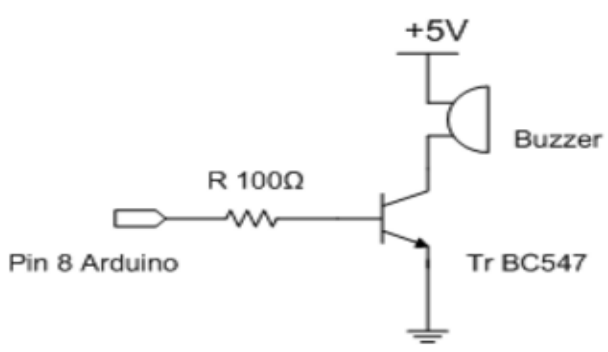

Gambar 9. Rangkaian Buzzer dengan $\operatorname{Tr} B C 547$

Prinsip kerja rangkaian driver diatas adalah dengan memanfaatkan transistor sebagai penguat arus dan saklar elekronik. Jika pin arduino yang terhubung dengan kaki basis (B) transistor BC547 mengeluarkan tegangan logika "1" alias tegangan $5 \mathrm{~V}$, maka tegangan ini akan membuat transistor dalam keadaan saturasi, sehingga arus mengalir dari kaki collector (C) ke kaki emitter (E), seperti pada gambar 8 dibawah ini, dengan demikian buzzer akan mendapatkan tegangan positif dan negatif sehingga buzzer akan hidup dan mengeluarkan output berupa bunyi.

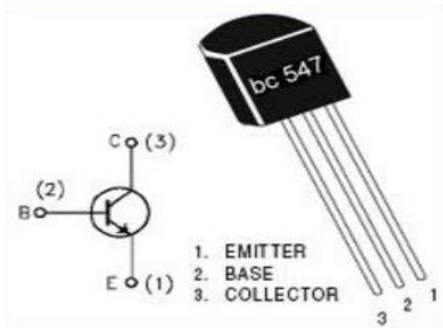

Gambar 10. Transistor bc547

Jika arduiono mengeluarkan tegangan logika 0 atau $0 \mathrm{~V}$, maka transistor berada pada posisi OFF karena basis-emitter kurang dari 0,7V. dengan demikian tidak ada arus yang mengalir dari kaki collector ke emitter dan buzzer kondisi OFF pula (tidak mengeluarkan bunyi).

\section{LITERATURE REVIEW}

Sedikit penelitian yang sebelumnya (literature review) dilakukan mengenai pembahasan tentang betaSPC, itu pun sumber yang didapat berasal dari penelitian luar (jurnal di luar). Dalam melakukan pengembangan sistem betaSPC ini perlu dilakukan studi pustaka untuk dijadikan sebagai bahan acuan untuk memperkuat hasil penelitian dengan cara mengindentifikasikan metode yang pernah dilakukan, mengembangkan penelitian sebelumnya yang memiliki korelasi yang seimbang dengan Penelitian ini. Adapun beberapa literature review yang didapakan dari jurnal di internet akan dijelaskan, sebagai berikut:

1. Penelitian yang dilakukan oleh Reem Alatas pada tahun 2014 dengan judul "Postuino: Bad Posture Detector Using Arduino". Penelitian ini menggunakan Sistem embedded berbasis mikrokontroler arduino sebagai alat pemantau kesehatan. Sistem ini berkaitan dengan sistem koreksi postur tubuh saat duduk dikomputer yang memanfaatkan sensor ultrasonic. Sensor akan mendeteksi ketika postur tubuh tidak sesuai dengan yang di inginkan, yaitu terlalu dekat dengan monitor. Sistem ini dasari karena banyak pengguna komputer yang mengalami gangguan pada mata karena terlalu dengan dengan monitor komputer. Alat yang digunakan adalah arduino mikro sebagai otaknya atau mikrokontroler, sensor ultrasonik, speaker, resistor, jump wires dan LED (Light Emiting Diode). ${ }^{(1)}$

2. Penelitian yang dilakukan oleh Wenyao $\mathrm{Xu}$ dan Ming Chun Huang dkk, pada tahun 2011 dengan judul "eCushion: An eTextile Device for Sitting Posture Monitoring". Penelitian ini bertujuan untuk mengetahui dan menganalisa postur duduk yang baik dan nyaman dengan di monitoring melalui aplikasi. Dari situlah dibuat perangkat eTextile yang disebut eCushion. Alat ini dapat menganalisis posisi posture duduk manusia secara akurat dan non-invasif. Pertama membahas tentang pelaksanaan eCushion dan desain tantangan data penginderaan, seperti skala, offset, rotasi dan lainnya. Kemudian beberapa teknik yang efektif 
yang diusulkan untuk meningkatkan level monitoring postur duduk. Dari hasil eksperimen, hasil menunjukan bahwa tingkat pengenalan eCushion bisa mencapai $92 \%$ untuk kasus berorientasi object (OOAD) dan 79\% untuk suatu kasus yang bersifat general (umum). ${ }^{(5)}$

3. Penelitian yang dilakukan oleh Robert Rakay dan Martin Visnovsky dkk, pada tahun 2015 dengan judul "Testing Properties of E-health System Based on Arduino". Dalam penelitian ini menghasilkan suatu sistem yang memberikan fungsi monitoring untuk mengamati karakteristik fisik pasien di rumah sakit. Menggunakan sensor untuk mengamati karakteristik fisik pasien dan informasi output disiarkan melalui ZigBee ke PC untuk diproses lebih lanjut, Pengujian sistem e-health ini berbasis arduino dan Zigbee untuk informasi transmisi dan PC untuk menerima data. Bluetooth dikenal sebagai protokol transfer data konvensional secara nirkabel (tanpa kabel) tetapi itu tidak dapat menjangkau aplikasi dengan jarak yang jauh dan durasi waktu yang panjang karena keterbatasan konsumsi daya sehingga zigbee menawarkan solusi yang lebih baik untuk kasus tersebut. Tugastugas dasar dari sistem ini adalah untuk mengukur fungsi kesehatan utama seperti denyut jantung, suhu tubuh, dan posisi tubuh. Dengan sistem ini memungkinan akses cepat ke parameter dimonitori biosignals karena itu identifikasi resiko kesehatan dan intervensinya dapat tersedia secara real-time. $^{(3)}$

4. Penelitian yang dilakukan oleh $\mathrm{Ch}$ Srikanth, dan D S Pradeep M dkk, pada tahun 2014 dengan judul "Smart Embedded Medical Diagnosis using Beaglebone Black and Arduino". Hasil dari konsep penelitian yang dibuat ini adalah memantau tubuh pasien dengan 9 sensor yang berbeda. Informasi ini dapat untuk memantau secara realtime data pasien dari suatu negara, untuk mendapatkan data sensitif agar selanjutnya di diagnosis secara medis. Informasi biometrik yang dikumpulkan dapat secara nirkabel dikirim menggunakana salah satu dari 6 pilihan konektivitas yang tersedia:
(1) Bluetooth, (2) 802.15.4, (3)Zigbee, (4) Wi-Fi, (5) 3G, dan (6) GPRS. ${ }^{(4)}$

5. Penelitian yang dilakukan oleh Jefri Gumilar Pratama, Afriyudi, dan Ilman Zuhri Yadi pada tahun 2012 dengan judul "Analisa Sistem Informasi Entri Krs Online Pada Universitas Bina Darma Dengan Menggunakan Metode End-User Computing (Euc) Satisfaction". Dari hasi penelitian ini menjelaskan tentang mekanisme duduk yang nyaman pada pengguna kursi roda, mekanisme yang dimaksudkan adalah untuk meningkatkan independensi pengguna kursi roda tetap terjaga. Pengguna kursi roda dapat menyesuaikan kursi hanya dengan menekan tombol. Kursi ini juga dilengkapi dengan tekanan pada bantalan yang lembut dengan sensor yang dapat dilakukan sesuai dengan keinginan di user. (2)

Dari ke-lima literature review yang ada, telah banyak penelitian mengenai metode Alat Bantu Kesehatan dari posture duduk manusia. Namun dapat disimpulkan pula bahwa belum ada peneliti yang secara khusus membahas mengenai BetaSPC (Sitting Posture Correction). Dimana seseorang dapat menjaga posture tubuhnya agar tetap berada dalam posisi yang baik dan benar. Yaitu duduk posisi tubuh yang tegak lurus, tidak condong ke depan. Sehingga bisa menghindari berbagai penyakit akibat kasus itu.

\section{PEMECAHAN MASALAH}

Desain dari Alat ini disisipkan pada pakaian yang dipasang sensor IR Infrared dan meletakannya pada titik yang benar. Itu artinya, sensor tersebut diletakan pada posisi dimana posture tubuh ketika membungkuk pakaian akan tertarik dan ketika tubuh tegak maka pakaian akan terlipat. Disini peneliti memasangkan di belakang pakaian di bagian tengah, tepat dipunggung bagian tulang belikat, dan sensor akan dipasangkan dibagian tersebut. Untuk lebih jelaskan maka dapat dilihat pada gambar 11 dibawah ini: 


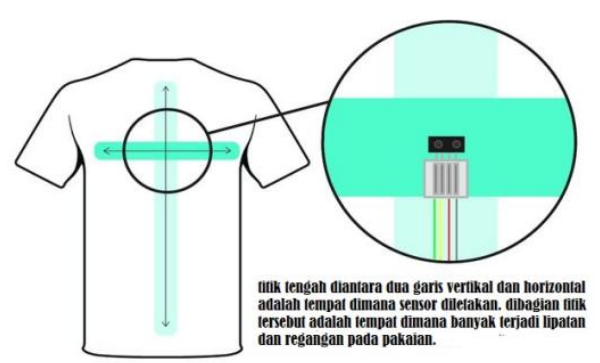

Gambar 11. Sensor IR Infrared pada Pakaian

Sensor Infrared akan mengidentifikasi berdasarkan perubahan pada bentuk pakaian dari terlipat dan meregang. Ketika pakaian meregang maka sensor akan mengirimkan sinyal untuk mengaktifkan buzzer berupa suara atau getaran dan lampu indikator LED bahwa posisi postur tubuh sedang membukuk. Ketika kita meluruskan tubuh maka pakaian akan terlipat dan sensor akan berlogika "0" tidak diaktifkan.

\section{FLOWCHART}

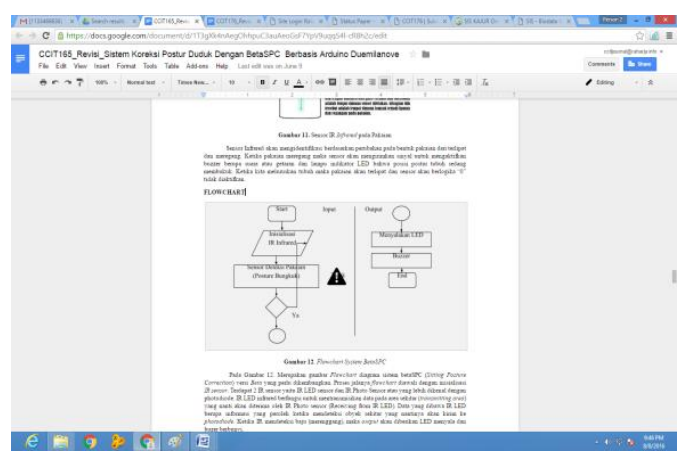

Gambar 12. Flowchart System BetaSPC

Pada Gambar 12. Merupakan gambar Flowchart diagram sistem betaSPC (Sitting Posture Correction) versi Beta yang perlu dikembangkan. Proses jalanya flowchart diawali dengan inisialisasi IR sensor. Terdapat 2 IR sensor yaitu IR LED sensor dan IR Photo Sensor atau yang lebih dikenal dengan photodiode. IR LED infrared berfungsi untuk mentransmisikan data pada area sekitar (transmitting area) yang nanti akan diterima oleh IR Photo sensor (Receiving from IR LED). Data yang dibawa IR LED berupa informasi yang peroleh ketika mendeteksi obyek sekitar yang nantinya akan kirim ke photodiode. Ketika IR mendeteksi baju (merenggang), maka output akan diberikan LED menyala dan buzer berbunyi.

\section{LISTING PROGRAM}

Dalam Implementasinya, sistem BetaSPC menggunaan LED dan Buzzer notifikasi (reminder) yang dikirim ke user Perguruan Tinggi Raharja, berikut ini yaitu koding program Arduino Duemilanove:

int IRpin $=\mathrm{A} 0$ // IR photodiode dihubungkan ke analog pin A0

int IRemitter $=2$; // IR emitter LED dihubungkan ke digital pin 2

int ambientIR; // variabel untuk menyimpan IR datang dari sekitar

int obstacleIR; // variabel untuk menyimpan the IR datang dari obyek

int value[20]; // variabel untuk menyimpan nilai IR

float posture; // variabel yang meberikan informasi jika postur salah

void setup()\{

Serial.begin(9600);

initializing Serial monitor

pinMode(IRemitter,OUTPUT);

IR emitter LED dihubungkan pada digital pin 2

digitalWrite(IRemitter,LOW);// pengaturan IR LED as off

pinMode(11,OUTPUT);

visual feedback dihubungkan pada digital pin 11

\}

void loop ()\{ 


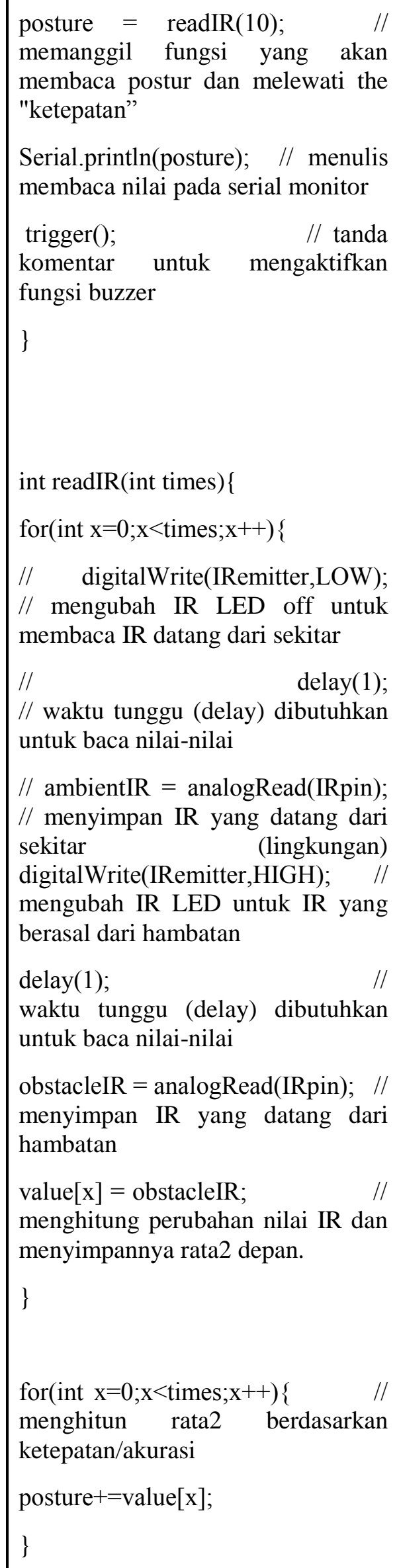

Pada kode program yang berwarna merah diatas adalah posisi posture tubuh ketika duduk dalam posisi membukuk, untuk mengatur ini harus disesuaikan karena setiap orang memiliki posture tubuh yang berbeda, sehingga angkanya akan berbeda. Pada koding diatas peneliti menyesuaikan dengan diri sendiri.

\section{IMPLEMENTASI}

Sebuah refleksi sensor yang berisi emittor dan bagian penerima (receiver) ditempatkan terhadap pakaian. Ketika pakaian tidak meregang. Sebagian besar IR Sensor yang dikirim oleh emitter di terima kembali oleh penerima. Ketika pakaian meregang. Tidak ada (sedikit) material kerutan pakaian di depan sensor. Ini artinya bahwa cahaya IR yang kurang dari pakaian akan tercermin dan diterima oleh penerima. Perbedaan ini akan digunakan untuk memberikan peringatan dan informasi kepada user. Dan kemudian mengaktifkan buzzer (suara/getaran) dan LED akan memberikan feedback user tentang perubahan postur.

Sistem BetaSPC (Sitting Posture Correction) versi Beta sedang dalam tahap uji coba dan sedang proses pengembangan. Di dalam sistem BetaSPC ini user diberikan kemudahan yaitu dapat mengetahui dan melakukan posisi duduk yang benar ketika berada didepan komputer atau laptop. Karena 
sistem akan memberikan notifikasi berupa sebuah cahaya LED dan buzzer ketika posisi tubuh membungkuk. Pada pengembangannya nanti diharapkan user dapat melihat posisi tubuh secara digital dan dapat menambah beberapa sensor pada beberapa titik yang mengganggu kesehatan ketika menggunakan komputer (laptop).

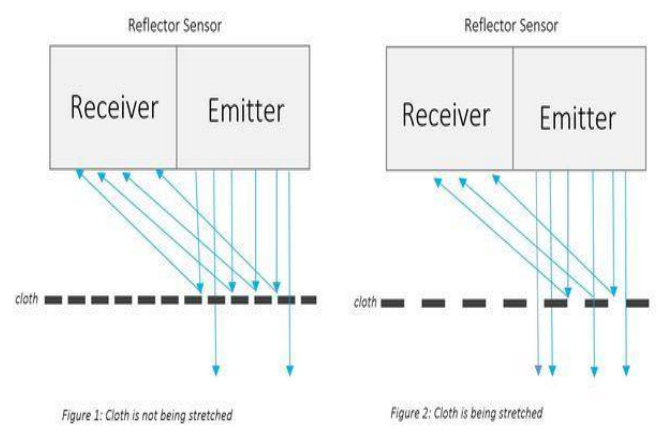

Gambar 13. Refleksi Sensor Receiver dan Emitter

Untuk melihat rangkaian skematik secara keseluruhan bisa dilihat pada gambar 14, yang ada dibawah ini:

\section{Komponen Hardware:}

a. Kabel Jumper

b. Kabel USB Port (Arduino to PC)

c. Arduino Duemilanove

d. Buzzer

e. LED

f. IR Sensor (Emitter dan Receiver)

h. sensor (sensor mount)

g. Resistor (10k)

h. Breadboard (Project Board)

i. LEM (Perekat sensor ke Pakaian)

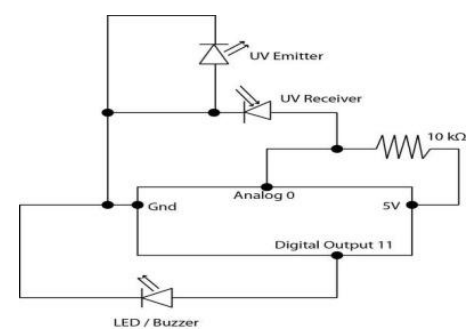

Gambar 14. Skematik Rangkaian BetaSPC

\section{JENIS-JENIS SENSOR}

\section{SENSOR ACCELEROMETER DAN GYROSCOPE}

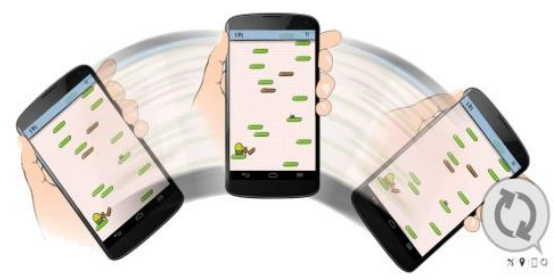

Gambar 15. Prinsip Kerja Accelometer

Accelerometer merupakan alat sensor yang peka terhadap gerak linier terhadap 3 sumbu gerakan yakni kanan-kiri, atas-bawah dan depan belakang. Sedangkan gyroscope merupakan suatu sensor yang dapat mendeteksi gerak rotasi dari suatu benda dimana peka terhadap 3 sumbu putaran yakni roll,pitch dan yaw seperti yang dapat dilihat pada gambar 16 putaran gyroscope yang ada sebagai berikut, yaitu:

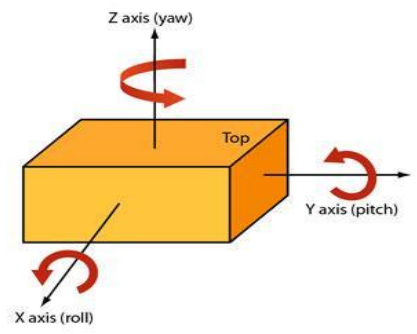

Gambar 16. Putaran Gyroscope

Gyroscope memiliki output yang peka terhadap kecepatan sudut dari arah sumbu x yang nantinya akan menjadi sudut phi (roll), dari sumbu y nantinya menjadi sudut theta (pitch), dan sumbu z nantinya menjadi sudut psi (yaw). Penggunaan giroscope dalam kehidupan sehari belum banyak. Gyroscope lazimnya digunakan pada Pesawat, Kapal, Helikopter. Namun akhir-akhir ini di smartphone. 
ISSN : 1978 -8282

Tabel 4. Perbandingan Sensor Gyroscope dan Accelerometer

\begin{tabular}{|c|c|c|c|c|c|}
\hline $\begin{array}{l}\text { Varian } \\
\text { Sensor }\end{array}$ & $\begin{array}{c}\text { Natura } \\
1 \\
\text { Freque } \\
\text { ncy }\end{array}$ & $\begin{array}{c}\mathrm{Nu} \\
\mathrm{mb} \\
\mathrm{er} \\
\text { of } \\
\mathrm{Ax} \\
\text { es }\end{array}$ & $\begin{array}{l}\text { Damp } \\
\text { ing } \\
\text { Coefic } \\
\text { ient }\end{array}$ & $\begin{array}{l}\text { Scal } \\
\text { e } \\
\text { Fact } \\
\text { or }\end{array}$ & $\begin{array}{l}\text { Comparis } \\
\text { on in } \\
\text { Sensor }\end{array}$ \\
\hline $\begin{array}{l}\text { Sensor } \\
\text { Accele } \\
\text { romet } \\
\text { er }\end{array}$ & $>5 \mathrm{kHz}$ & $\begin{array}{l}\text { Up } \\
\text { to } \\
3\end{array}$ & Small & $\begin{array}{c}\text { Out } \\
\text { put } \\
\text { Hig } \\
\text { h }\end{array}$ & $\begin{array}{l}\text { Diguna } \\
\text { kan } \\
\text { Dalam } \\
\text { Suatu } \\
\text { Vibrasi } \\
\text { (vibrati } \\
\text { on), } \\
\text { atau } \\
\text { Goyang } \\
\text { an } \\
\text { (shake) } \\
\text {.. }\end{array}$ \\
\hline $\begin{array}{l}\text { Sensor } \\
\text { Gyros } \\
\text { cope }\end{array}$ & $>5 \mathrm{kHz}$ & $\begin{array}{l}\text { Up } \\
\text { to } \\
3\end{array}$ & $\begin{array}{l}\text { Mediu } \\
\mathrm{m}\end{array}$ & $\begin{array}{c}\text { Out } \\
\text { put } \\
\text { Hig } \\
\text { h }\end{array}$ & $\begin{array}{l}\text { Digunaka } \\
\mathrm{n} \text { deteksi } \\
\text { untuk } \\
\text { kecepatan } \\
\text { grafitasi. }\end{array}$ \\
\hline
\end{tabular}

\section{SENSOR FLEX}

Sensor flex adalah sensor yang berfungsi untuk mendeteksi suatu kelengkungan Prinsip kerjanya sama seperti potensio. Untuk menggunakan sensor flex kita membutuhkan rangkaian pembagi tegangan. Sensor flex dapat di aplikasikan pada beberapa perangkat, biasanya digunakan sebagai pengontrol game pada sarung tangan pengendali. Selain pada aplikasi game sensor flex juga biasa digunakan untuk pengontrolan robot, sebagai pembaca isarat tangan digital, seperti gambar dibawah ini:

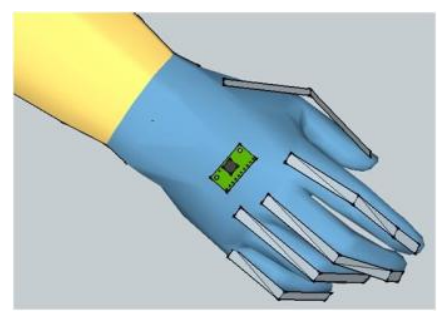

Gambar 22. Sarung tangan pengontrolan

\section{PERBANDINGAN VARIAN SENSOR}

Tabel 5 Perbandingan Pada Sensor IR

\begin{tabular}{|c|c|c|c|c|c|}
\hline $\begin{array}{l}\text { Varian } \\
\text { Sensor }\end{array}$ & $\begin{array}{l}\text { Pri } \\
\text { ce }\end{array}$ & $\begin{array}{c}\text { Environm } \\
\text { ent }\end{array}$ & $\begin{array}{c}\text { Acc } \\
\text { ura } \\
\text { cy }\end{array}$ & $\begin{array}{l}\text { Sensiti } \\
\text { vity }\end{array}$ & $\begin{array}{l}\text { Compa } \\
\text { rison }\end{array}$ \\
\hline $\begin{array}{c}\text { Sensor } \\
\text { Acceler } \\
\text { ometer }\end{array}$ & $\begin{array}{l}\text { Lo } \\
\text { w }\end{array}$ & Standard & $\begin{array}{l}\text { Var } \\
\text { ies }\end{array}$ & Good & $\begin{array}{l}\text { Vibrati } \\
\text { on and } \\
\text { Shake }\end{array}$ \\
\hline $\begin{array}{c}\text { Sensor } \\
\text { Gyrosc } \\
\text { ope }\end{array}$ & $\begin{array}{l}\mathrm{Hig} \\
\mathrm{h}\end{array}$ & Standard & $\begin{array}{l}\mathrm{Hig} \\
\mathrm{h}\end{array}$ & Good & $\begin{array}{l}\text { Detecti } \\
\text { on } \\
\text { Move } \\
\text { ment } \\
\text { Any } \\
\text { Angle }\end{array}$ \\
\hline $\begin{array}{l}\text { Sensor } \\
\text { Flex }\end{array}$ & $\begin{array}{c}\text { Me } \\
\text { diu } \\
\text { m }\end{array}$ & Standard & $\begin{array}{l}\text { Var } \\
\text { ies }\end{array}$ & Good & $\begin{array}{c}\text { Move } \\
\text { ment } \\
\text { Robot } \\
\text { Arm }\end{array}$ \\
\hline $\begin{array}{c}\text { IR } \\
\text { Sensor }\end{array}$ & $\begin{array}{c}\text { Lo } \\
\text { w }\end{array}$ & $\begin{array}{c}\text { - Contac } \\
\text { ting } \\
\text { - Sensiti } \\
\text { ve }\end{array}$ & $\begin{array}{c}\mathrm{Hig} \\
\mathrm{h}\end{array}$ & Good & $\begin{array}{c}\text { Contai } \\
\mathrm{n} \text { as a } \\
\text { emmit } \\
\text { er and } \\
\text { receive } \\
\text { r, } \\
\text { (Reflec } \\
\text { tive } \\
\text { Sensor } \\
\text { ) }\end{array}$ \\
\hline
\end{tabular}

DESAIN PROTOTIPE ALAT

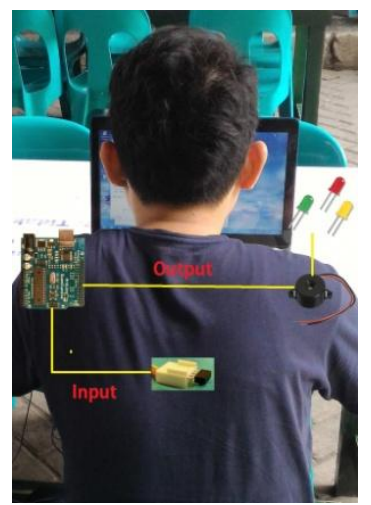

Gambar 15. Diagram Blok Desain BetaSPC

IR INFRARED SENSOR 
Sensor IR Infrared akan merefleksikan setiap perubahan yang terjadi pada pakaian saat posture tubuh membungkuk seperti yang terlihat digambar 15 maka sensor IR akan mendeteksi kemudian akan mengirim informasi ke Arduino Duemilanove untuk bisa diterjemahkan sebagai output, output yang dihasilkan berupa signal berupa indikator LED akan menyala jika sensor menerima input (sensor aktif) dan buzzer akan berbunyi pada saat lampu indikatornya menyala.

\section{PENGUJIAN SENSOR TCRT1000}

Tabel 6 Karakteristik Dasar Sensor TCRT1000

\begin{tabular}{|c|c|c|c|c|c|c|}
\hline PARAMETER & TEST CONDITION & \multicolumn{2}{|c|}{ SYMBOL MIN. } & TYP. & MAX. & UNIT \\
\hline \multicolumn{7}{|l|}{ SENSOR } \\
\hline $\begin{array}{l}\text { Collector emitter } \\
\text { saturation voltage } \\
\end{array}$ & $\begin{array}{l}\mathrm{IF}=20 \mathrm{~mA}, \\
I_{C}=0.1 \mathrm{~mA}\end{array}$ & \multicolumn{2}{|l|}{ VCEsat } & & 0.3 & V \\
\hline \multicolumn{7}{|l|}{ INPUT (EMITTER) } \\
\hline Forward voltage & If $=50 \mathrm{~mA}$ & \multicolumn{2}{|l|}{$V_{F}$} & 1.25 & 1.6 & V \\
\hline Peak wavelength & $I_{F}=100 \mathrm{~mA}$ & ip & 940 & & & $\mathrm{~nm}$ \\
\hline \multicolumn{7}{|l|}{ OUTPUT (DETECTOR) } \\
\hline Collector emitter & $I C=1 \mathrm{~mA}$ & VCEO & 32 & & & V \\
\hline Emitter collector & $\mathrm{IE}=100 \mu \mathrm{A}$ & VECO & 5 & & & V \\
\hline Collector dark current & $V_{C E}=20 \mathrm{~V}, I_{F}=0 \mathrm{~A}$ & ICEO & & & 200 & $n A$ \\
\hline
\end{tabular}

Datasheet menyediakan grafis untuk dasar karakteristik, dan satu grafis yang menarik untuk tujuan desain sensor. Gambar dibawah ini menunjukkan hubungan antara arus kolektor dan perpindahan terhadap objek penginderaan. perpindahan objek penginderaan yang berbeda reflektifitas material akan dipakai dalam desain akhir. Menurut grafik, perubahan linear pada arus kolektor terjadi di kisaran $2 \mathrm{~mm}$.

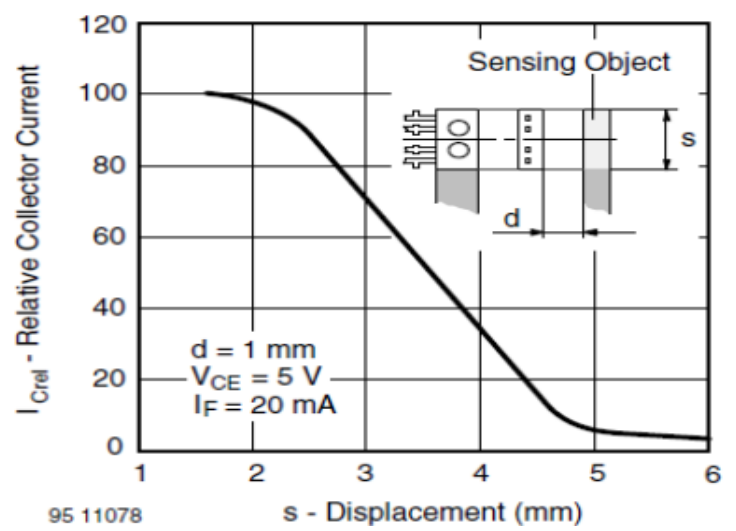

Gambar 16. Arus kolektor dan perpindahan pada sensor TCRT1000

Sebuah sirkuit elektronik yang sangat sederhana dirancang untuk memasok arus yang diperlukan untuk alat. Dalam rangka mencapai nilai nominal di datasheet, nilai untuk resistor untuk membatasi arus dalam emitor dihitung dengan persamaan berikut. Nilai untuk saat ini diambil sebagai nilai yang dapat diubah, dan hal itu berkaitan akan langsung dengan $\mathrm{fv}$ (forward voltage). Menurut grafis dalam datasheet, ke vf memiliki nilai sekitar 1,1 Volt. Nilai ini untuk detektor yang akan diuji nanti untuk memeriksa kinerja, apakah kurang atau lebih pada saat ini.

$$
R_{\text {emitter }}=\frac{V_{c c}-V_{F}}{I_{F}}=\frac{5-1.1}{0.02}=190 \Omega
$$

Gambar 17. Persamaan Remitor

Untuk membatasi arus detektor, nilai yang dapat berubah yang lainnya akan digunakan, karena digunakan sebagai pull-down resistor. Dengan cara itu, transistor dapat membatasi arus atau aliran dicabang, demikian tegangan dari resistor.

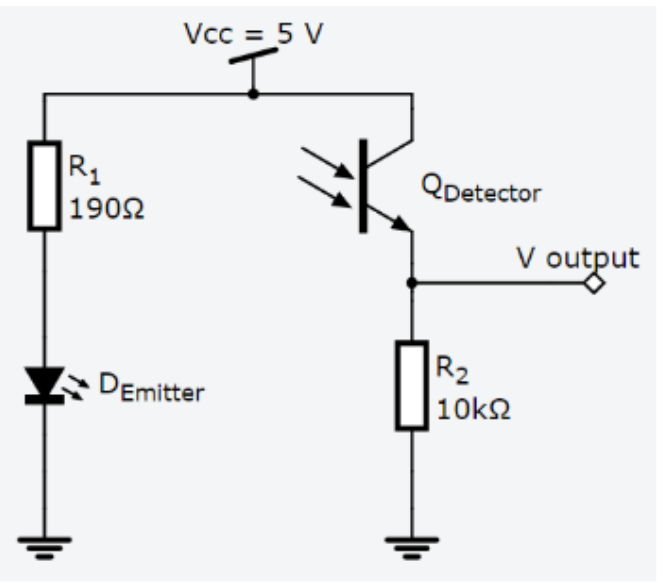

Gambar 18. Skematik IR TCRT1000

Sinyal output akan berubah dalam domain digital secara terintegrasi Analog to Digital Converter (ADC) dari platform Arduino. ADC memiliki Resolusi 10-bit, yang tidak cukup untuk resolusi yang diinginkan, tapi akan cukup untuk uji coba linear. Pada desain akhir, Resolusi ADC yang akan lebih di implementasi.

\section{KESIMPULAN}

Dengan demikian, maka hasilnya dapat disimpulkan bahwa Sistem BetaSPC adalah sistem yang dapat mengidentifikasi postur tubuh ketika dalam posisi duduk menggunakan komputer dengan disisipkan pada sebuah pakaian yang bekerja dengan 
memberikan notifikasi (reminder) kepada user berupa cahaya LED dan Buzzer ketika posisi tubuh membungkuk dan pakaian meregang. Penelitian ini dilakukan pada Perguruan Tinggi Raharja karena Perguruan Tinggi Raharja adalah kampus yang melingkupi sebagian besar jurusan dalam ilmu komputer dan informatika. Sehingga sebagian besar bahan pembelajaran dan pengajaran menggunakan perangkat komputer atau laptop. Sistem Beta SPC akan sangat bermanfaat bagi mahasiswa ataupun staff pribadi raharja bagi kesehatan dalam rutinitas di pekerjaaan yang menggunakan komputer saat mengerjakan komputer dalam waktu lama sehingga baik memperbaiki posisi postur duduk.

\section{SARAN}

sederhana sekali dalam pengimplementasianya, diharapkan penelitian bisa dikembangkan secara maksimal baik pada sisi hardware maupun penggunaan terhadap software dari aplikasinya.

\section{DAFTAR PUSTAKA}

[1] Alattas, Reem. 2014. "Postuino: Bad Posture Detector Using Arduino". IJISR (International Journal of Innovation and Scientific Research) ISSN 2351-804 Vol. 3 No. 2 University of Bridgeport, CT USA, Jun 2014.

[2] Hsu Pro Er, Yeh Liang Hsu, Jun Ming lu, dan Cheng-Hao Chang. 2013. "Seat Adjustment Design of an Intelligent Robotic Wheelchair Based on the Stewart Platform". International Journal of Advanced Robotic Systems. Vol 10, 168: 2013. Yuan Ze University, Taoyuan, Taiwan.

[3] Rakay Robert, Martin Visnovsky, Alena Galajdova, Dusan Simsik . 2015. "Testing Properties of E-Health System Based Arduino". Journal of Automation and Control. Vol. 3, No. 3, 122-126, University of Kosice, Slovak Republic.

[4] Srikanth Ch, D S Pradeep M, Sreeram Charan K. 2014. "Smart Embedded Medical Diagnosis using" International Journal of Engineering Trends and Technology (IJET), Vol.8, No.1, Feb. 2014.
[5] Xu, Wenyao, Zhinan li, Ming Chun Huang, Navid Amini and Majid Sarrafzadeh. 2011. "eCushion: An eTextile Device for Sitting Posture Monitoring". International Conference of Body Sensor Network. University of California, Los Angeles and University of Peking (China). 